\title{
Inquietud del auditorio
}

\section{Édgar Alonso Rodríguez-López}

$\mathrm{D}$

e las prácticas detestables en la Facultad no me extrañaba; me extrañaba de mi ingenuidad para volver a caer en la simulación. Y también de ver a Gabriela ahí en el auditorio, completamente sola y esperándome, tal vez pensando que al fin era salvada de la solitaria vergüenza de haber caído, como yo, en otro evento vacío. Pero ya qué más da si la Secretaría Académica invita - o acarrea, más bien - al grupo de sexto semestre para llenar la proyección de un documental que nadie quiere ver, pero que viene de parte del invitado británico sumamente importante para las relaciones universitarias. Total, puede ser bueno. Total, Gaby y yo estábamos solos y el "inge” Ochoa puso play y se largó, así que estábamos solos y...

Así que sonreí lascivamente desde la puerta y le guiñé un ojo seductor a Gaby. Se había sentado por el centro, en la décima fila. Entonces, como cualquiera en esa situación, desde esta esquina calculé la fila donde se ubicaba para cruzar luego hacia el otro lado. Me sentí en una sala de cine. Subí los escalones y llegué a donde comenzaba la décima. Ya había iniciado el documental y el resplandor intermitente me confundía de pronto los pasos. Crucé la fila mientras una pantalla oscura permanecía en la proyección. Luego se alumbró todo de nuevo y me encontré a mitad de la fila diez: una fila vacía, mientras que Gaby estaba realmente debajo, por la séptima: su silueta fastidiada levantando los brazos, reclamando explicación. Había calculado mal, por supuesto. 
Bajé la escalera por el otro extremo cuando una mujer lloraba ante las preguntas del director entrometido. Con un ojo en la cabeza de Gaby y otro en el descenso de los escalones, llegué al inicio de la fila correcta. Tropecé mientras se proyectaba el trávelin de un río. Por fin, ya agobiado, me dejé caer en la silla junto a Gaby para voltear luego a mi lado y notar que no había nadie en toda esa fila. Arriba, con la voz de albañil en cruda que le sale a veces, Gaby se quejaba de mi estupidez. También a mí me desconcertaba la torpeza de mis búsquedas fallidas, pero se la achacaba a la oscuridad, a la obnubilación de la luz y muy poco a mi habitual desatención.

Más idiota parecí cuando bajé hasta la primera fila para calcular con exactitud topográfica la ubicación de mi Gaby querida —y enfadada—. Fila ocho. Butaca... seis. Volví a subir por el extremo derecho, lentamente; un paso y mirar a la izquierda, un paso y encontrar a Gaby. Subir con atención milimétrica. Flashbacks de contexto histórico en la película. Naturalmente, en blanco y negro. Poco original, por cierto. Relampagueos tenues y confusión: la cinco, la seis. Ocho entre la negrura repentina del auditorio y Gaby esperando, desesperada. Camino hacia el medio de la fila cuidando los pies y tanteando con la punta de los dedos. Y Gaby no está... Plenamente idiota, pero ahora en blanco y negro y aturdido, sorprendo a Gaby abajo, en la entrada: manos a la cintura y mueca de un odio que no conocía. Qué pena.

Ya quiere irse, obviamente. No aguanta más mis tonterías.

(De pronto tengo la intuición de que esto es una metáfora. La imposibilidad del amor. No. La otredad inalcanzable. Gabriela lejana, Gabriela sin asidero... Casi estoy seguro de que me encuentro en una situación metafórica. En fin.)

Bajo apresurado, ya sin tantear y entre deslumbres, con la certeza de haber encontrado la idea para un cuento, tal vez. Ensimismado y a zancadas. Entonces la entrada vacía. Entonces un idiota más, el mismo. Fruncir el ceño y no ver nada, nadie. Rascarse la nuca, abrir ridículamente la boca. Voltear a las butacas y mirar que Gaby sigue, como al principio, en la séptima fila: alumbrada la cara de furia. Imposible. Yo, en mi gesto inaudito frente a lo ominoso, me decido. Salir, correr fuera del auditorio. El amor inalcanzable... Asustado, un idiota asustado y ahora también solo.

Édgar Alonso Rodríguez López. Nació en la ciudad de Chihuahua en 1997. Publicó el libro de cuentos Bajo la cama en la colección Soltar las amarras del Instituto de Cultura del Municipio. También ha publicado cuentos en la revista Metamorfosis de la Facultad de Filosofía y Letras de la Universidad Autónoma de Chihuahua (UACH), México. Ha participado en el Coloquio Nacional Palafoxiano de Estudiantes de Lingüística y Literatura y en diversas ocasiones en el Encuentro Nacional de Escritores Jóvenes Jesús Gardea. Además, ha sido juez del concurso Don Quijote Nos Invita a Leer. Actualmente, cursa el octavo semestre de la Licenciatura en Letras Españolas en la UACH y forma parte del Colectivo Cultural Luvina, encargado de proyectos de gestión y promoción cultural.

Recibido: 11 de enero de 2019

Aprobado: 23 de enero de 2020 